\title{
Odstąpienie od rezultatów wykładni językowej w prawie karnym (na kanwie uchwały Sądu Najwyższego z dnia 26 marca 2009 r., I KZP 35/08)
}

\author{
Departure from the results of linguistic interpretation in penal law \\ (on the basis of the resolution of the Supreme Court of 26 March \\ 2009, I KZP 35/08)
}

\section{STRESZCZENIE}

Artykuł opisuje sytuacje, w których dopuszczalne jest odstąpienie od wyników wykładni językowej. Te przypadki wyliczył L. Morawski, co następnie zostało zaadaptowane przez Sąd Najwyższy na gruncie prawa karnego. Spotkało się to jednak z zarzutem, iż akceptacja takiego postępowania prowadzi do zaakceptowania wykładni prawotwórczej. Analiza powyższych przypadków prowadzi do wniosku, że wyjście poza wykładnię językową w prawie karnym jest generalnie dopuszczalne, o ile nie stanowi wykładni rozszerzającej na niekorzyść sprawcy i ma oparcie w wykładni systemowej i funkcjonalnej.

Slowa klucze: prawo karne; wykładnia; Sąd Najwyższy.

\section{WPROWADZENIE}

W teorii prawa utrwaliło się przekonanie o pierwszeństwie wykładni językowej i pomocniczym charakterze wykładni systemowej i funkcjonalnej ${ }^{1}$. Jak pisze L. Morawski, uzasadnieniem takiego podejścia są argumenty analityczne (bowiem „wykładnia prawa jest wykładnią tekstów prawnych") i argumenty polityczne (co wynika z postulatu pewności prawa - obywatela wiąże rzeczywista treść tekstu prawnego,

1 Tak np. L. Morawski, Wstęp do prawoznawstwa, Toruń 2014, s. 146, 154-155; subsydiarny charakter wykładni systemowej wyraźnie przyjmuje także M. Zieliński, Wykładnia prawa. Zasady, reguły, wskazówki, Warszawa 2012, s. 237. 
a nie rzeczywiste bądź hipotetyczne intencje ustawodawcy²). To prowadzi do wniosku, że odstąpienie od rezultatów wykładni językowej może być uzasadnione jedynie ważnymi powodami prawnymi, społecznymi, ekonomicznymi lub moralnymi ${ }^{3}$.

Ten problem szczególnego znaczenia nabiera na gruncie prawa karnego, które w największym stopniu ingeruje w prawa i wolności człowieka i obywatela. W tym zakresie podkreśla się szczególne znaczenie wykładni językowej (pomijam przy tym, że na tym gruncie mamy do czynienia z językiem prawnym, językiem prawniczym, językiem specjalistycznym i językiem potocznym, a to samo pojęcie na gruncie tych języków może mieć różne znaczenie), co nie oznacza jednak jej bezwzględnego prymatu ${ }^{4}$. Jednakże, jak stwierdza A. Zoll, „Na gruncie prawa karnego dopuszczalny jest bowiem tylko taki wynik wykładni uzyskany z zastosowaniem innych metod, który mieści się jeszcze w zakresie tolerowanym przez wynik uzyskany za pomocą metody wykładni językowej"’5. Powyższy pogląd nie budzi zasadniczych wątpliwości również w orzecznictwie ${ }^{6}$.

Nie oznacza to oczywiście, że ,jednoznaczność językowa przesądza o konieczności zakończenia całego procesu wykładni, czyli wyznacza językowe granice całego procesu wykładni i wyraża sie cw dyrektywie interpretatio cessat in claris", ponieważ nawet w tych wypadkach należy stosować wszystkie trzy typy dyrektyw wykładni $^{7}$. Zgodnie z derywacyjną koncepcją wykładni prawa ,zadaniem wykładni prawa jest odtworzenie z przepisów prawnych norm postępowania wraz z ich percepcjąa" z uwzględnieniem klaryfikacyjnych elementów wykładni w znaczeniu wąskim (eliminowanie wieloznaczności) i w znaczeniu szerokim (czynienie jaśniejszym) ${ }^{9}$.

2 Zob. też uchwała SN z dnia 29 października 2004 r., I KZP 24/04, LEX nr 125547.

3 L. Morawski, Wstęp, s. 146.

4 A. Zoll [w:] Kodeks karny. Część ogólna, t. 1, cz. 1: Komentarz do art. 1-52, red. W. Wróbel, A. Zoll, Warszawa 2016, komentarz do art. 1, teza 90; podobnie P. Hofmański, S. Zabłocki, Elementy metodyki pracy sędziego w sprawach karnych, Warszawa 2011, s. 244-246; J. Wyrembak, Zasadnicza wykładnia znamion przestępstw. Pozycja metody językowej oraz rezultatów jej użycia, Warszawa 2009, s. 179-188. Na marginesie należy wymienić stanowisko wyrażone w wyroku SN z dnia 6 listopada 2003 r., III RN 133/02, OSNP 2004, nr 15, poz. 254, choć nie dotyczy on prawa karnego: „Sąd Najwyższy jest jednak zdania, że wykładnia językowa jest jedynie jednym z typów wykładni i nie korzysta w procesie sądowego stosowania prawa ani z priorytetu w stosunku do innych rodzajów wykładni, ani też nie wyznacza granic pozostałym rodzajom wykładni”.

5 A. Zoll [w:] Kodeks..., komentarz do art. 1, teza 91.

6 Co ilustruje uchwała SN z dnia 18 października 2001 r., I KZP 22/01, OSNKW 2001, nr 11-12, poz. 86. Więcej judykatów przywołuje J. Wyrembak, Zasadnicza, s. 179-188 (postanowienie SN z dnia 8 lutego 2000 r., I KZP 49/99, LEX nr 39820; uchwała SN z dnia 21 grudnia 1999 r., I KZP 44/99, LEX nr 38572; postanowienie SN z dnia 3 listopada 2003 r., IV KK 295/02, LEX nr 82447).

7 M. Zieliński, Osiemnaście mitów w myśleniu o wykładni prawa, „Palestra” 2011, nr 3-4, s. 27-28; por. postanowienie SN z dnia 21 listopada 2001 r., I KZP 27/01, LEX nr 49714.

8 Tenże, Wykładnia, s. 85.

9 Tamże, s. 253. 


\section{DOPUSZCZALNOŚĆ ODSTĘPSTW OD REZULTATÓW WYKŁADNI JĘZYKOWEJ}

Sformułowanie kryteriów pozwalających wyjść poza rezultaty wykładni językowej ma niewątpliwie wysoką wagę, a to choćby ze względu na nullum crimen sine lege czy nulla poena sine lege, albowiem z tekstu prawnego ma wynikać wyraźnie, iż dane zachowanie $\mathrm{z}$ jednej strony zostało wyraźnie określone jako zabronione, a z drugiej poddano je określonej sankcji karnej. Karalności danego zachowania nie można bowiem domniemywać, ani przyjmować jedynie na podstawie intencji prawodawcy.

Sąd Najwyższy, wydając uchwałę w przedmiocie charakteru przestępstwa z art. $265 \S 1$ k.k., powołał się na wypadki określone przez L. Morawskiego. Zgodnie z tym poglądem odstąpienie od rezultatów wykładni językowej jest dopuszczalne:

- w przypadku gdy sens językowy jest ewidentnie sprzeczny z fundamentalnymi wartościami konstytucyjnymi, a z istotnych powodów uchylenie przepisu byłoby w danym momencie niemożliwe lub niecelowe,

- w przypadku gdy wykładnia językowa prowadzi do rozstrzygnięcia, które w świetle powszechnie akceptowanych wartości musi być uznane za rażąco niesłuszne, niesprawiedliwe, nieracjonalne lub niweczące ratio legis interpretowanego przepisu ${ }^{10}$,

- w sytuacji, gdy wykładnia językowa prowadzi ad absurdum,

- w sytuacji oczywistego błędu legislacyjnego ${ }^{11}$.

Co ciekawe, o czym jeszcze będzie mowa poniżej, najwyższa instancja sądowa, podejmując rozstrzygnięcie, opowiedziała się jednoznacznie za rezultatem wykładni językowej, pomijając wyniki pozostałych metod wykładni i prowadząc do znacznego rozszerzenia odpowiedzialności karnej. Wskazane orzeczenie dotyczy nie tylko teoretycznych aspektów wykładni tekstu prawnego, ale również jej praktycznych konsekwencji. Krytyczna analiza tego judykatu prowadzi do wniosku, że ważne racje gwarancyjne mogą przemawiać za zawężeniem rezultatów wykładni językowej, o ile nie prowadzi to do rozszerzenia odpowiedzialności karnej. Innymi słowy, zasady prawa karnego niekiedy wręcz wymuszają rezygnację z utrzymywania bezwzględnego prymatu wykładni językowej, choć wyznacza ona nieprzekraczalne ramy w jakich powinno się ustalać znaczenie danej normy.

10 Tamże, s. 238: „Jeśli w przypadku konfliktu rezultatów wykładni funkcjonalnej i językowej okaże się, że rezultat uzyskany w oparciu o reguły językowe burzy podstawowe założenia aksjologiczne o prawodawcy (zwłaszcza o jego systemie wartości), to należy dać pierwszeństwo rezultatowi uzyskanemu na gruncie zastosowania reguł funkcjonalnych". Zob. też tenże, Osiemnaście, s. 28.

11 Zob. uchwała SN z dnia 26 marca 2009 r., I KZP 35/08, OSNKW 2009, nr 5, poz. 33; zob. też L. Morawski, Wstęp, s. 146-147. 
Stanowisko SN, w zakresie w jakim dopuszcza odstąpienie od rezultatów wykładni językowej, zostało skrytykowane przez A. Zolla, który stwierdził: „Przyjęcie takiego stanowiska prowadzi jednoznacznie do kreatywnej wykładni sądowej, pozostającej w niezgodzie z konstytucyjną zasadą podziału władz. Wypadki, na które wskazuje SN, oznaczają konieczność zmiany ustawy przez powołany do tego organ władzy ustawodawczej, a nie de facto zmiany ustawy przez orzekający sąd"12.

Z poglądu sformułowanego przez A. Zolla można wysnuć wniosek, że zaakceptowanie powyższych wyjątków prowadzi w istocie do zaakceptowania wykładni prawotwórczej, która „zmienia zakres czynów nakazanych, zakazanych lub dozwolonych w stosunku do tego, który wynika z dotychczas obowiązujących norm prawnych, a tym samym tworzy nowe normy"13. Przy tym należy zwrócić uwage na to, że sam L. Morawski zastrzega, że sąd, odstępując od rezultatu wykładni językowej, powinien rozważyć, czy w konkretnej sytuacji nie byłaby bardziej wskazana interwencja ustawodawcy; powinien tylko w ostateczności wychodzić poza językowe brzmienie przepisu ${ }^{14}$.

\section{SPRZECZNOŚĆ Z FUNDAMENTALNYMI WARTOŚCIAMI KONSTYTUCYJNYMI}

Zachodzi pytanie, czy w przypadkach opisanych przez L. Morawskiego faktycznie mamy do czynienia z nieuzasadnioną wykładnią prawotwórczą, czy też można to usprawiedliwić odwołaniem się do pozostałych metod wykładni. Może przecież wystąpić przypadek, w którym ustawodawca ustanawia regulacje o jasnym brzmieniu językowym, aczkolwiek niezgodne z normami wyższego rzędu, np. z Konstytucją. Na tle niedawno wprowadzonego art. 12 § 2 k.k. („Odpowiada jak za jeden czyn zabroniony wyczerpujący znamiona przestępstwa ten, kto w krótkich odstępach czasu, przy wykorzystaniu tej samej albo takiej samej sposobności lub w podobny sposób popełnia dwa lub więcej umyślnych wykroczeń przeciwko mieniu, jeżeli łączna wartość mienia uzasadnia odpowiedzialność za przestępstwo") i pozostającego z nim w związku art. 10a k.w., jeszcze przed ich wejściem w życie, P. Kardas stwierdził: „Jest zupełnie oczywiste, że [...] sprawca czynu ciągłego powinien ponosić odpowiedzialność za przestępstwo, z pominięciem odpowiedzialności za wykroczenia zrealizowane czynami stanowiącymi elementy czynu ciągłego. W razie błędów popełnionych przez organy wymiaru sprawiedli-

12 A. Zoll [w:] Kodeks..., komentarz do art. 1, teza 92.

13 L. Morawski, Wstęp, s. 143; zob. też S. Majcher, W kwestii prawotwórstwa sądowego (na przykładzie orzecznictwa SN w sprawach karnych), „Państwo i Prawo” 2004, nr 2, s. 69-70; uchwała SN z dnia 11 stycznia 1999 r., I KZP 15/98, OSNKW 1999, nr 1-2, poz. 1.

14 L. Morawski, Wstęp, s. 147, 155. 
wości i wcześniejszego ukarania za wielość pozostających w realnym wieloczynowym zbiegu wykroczeń, zamiast za popełnione w warunkach czynu ciagłego przestępstwo, nie jest możliwe dokonanie korekty na niekorzyść sprawcy, bowiem oznaczałoby to ponowne ściganie, oskarżenie i ukaranie za ten sam czyn, a więc stanowiłoby naruszenie zasady ne bis in idem"15.

Mamy w tym wypadku do czynienia z sytuacją, w której ustawodawca wprowadza w życie przepisy, sprzeczne z przepisami rangi konstytucyjnej, pozwalające dwukrotnie pociągnąć konkretną osobę do odpowiedzialności represyjnej (najpierw za wykroczenie, a później za przestępstwo) za ten sam czyn pomimo zasady ne bis in idem. Wydaje się, że znajduje wówczas zastosowanie sytuacja określona przez SN (w ślad za L. Morawskim) jako stan, w którym ,sens językowy jest ewidentnie sprzeczny z fundamentalnymi wartościami konstytucyjnymi, a z istotnych powodów uchylenie przepisu byłoby w danym momencie niemożliwe lub niecelowe". Jest to powiązane z tzw. wykładnią prokonstytucyjną przepisów, traktowaną jako odmianę wykładni systemowej i celowościowej ${ }^{16}$.

Tu powstaje jednak poważna kontrowersja związana z dopuszczalnością swoistego „ominięcia” treści przepisu ze względu na jego niezgodność z Konstytucją. Jej przepisy stosowane są bezpośrednio (art. 8 ust. 2 Konstytucji), w szczególności gdy wykładnia poprzestająca jedynie na metodzie językowej prowadzi do ograniczenia konstytucyjnych praw i wolności człowieka i obywatela. Na tę sferę zasada ne bis in idem niewątpliwie wpływa. Nie rozstrzygając tego problemu, warto podkreślić, że w doktrynie prawa karnego przyjęto, że wykładnia prokonstytucyjna nie może prowadzić do prawotwórstwa i nie może prowadzić do podważenia jednoznacznego rezultatu wykładni językowej ${ }^{17}$. Jednocześnie A. Rychlewska przyjmuje, że „Tekst prawny poddać przeto należy analizie z punktu widzenia wszystkich dyrektyw interpretacyjnych, a to kolejno: językowych, systemowych i funkcjonalnych, także dyrektywie historycznej i porównawczej, czy - właśnie prokonstytucyjnej, w razie zaśs stwierdzenia ważnych racji (prawnych, społecznych lub moralnych) - odstąpić powinno się nawet od wykładni językowej. Stwierdzić należy, że zwłaszcza konieczność realizacji konstytucyjnych wartości uzasadniać będzie przekroczenie językowych granic wykładni" ${ }^{18}$.

Trudno również automatycznie uznać, że mamy w tym wypadku do czynienia $\mathrm{z}$ wykładnią prawotwórczą, bowiem odwołując się do norm wyższego rzędu

15 P. Kardas, Problem reakcji na tzw. czyny przepołowione w świetle ciągłości popełnienia przestępstwa, konstrukcji idealnego zbiegu czynów karalnych oraz zasady ne bis in idem, „Prokuratura i Prawo" 2018, nr 3, s. 35-36.

16 A. Rychlewska, O gwarancyjnym modelu wykładni prokonstytucyjnej przepisów typizujących czyny zabronione pod groźbą kary, „Czasopismo Prawa Karnego i Nauk Penalnych” 2016, z. 3, s. 138-139.

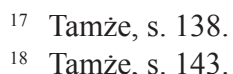


(o randze konstytucyjnej) organ stosujący prawo nie kreuje nowych norm, ale uznaje niektóre regulacje za niedające się zastosować z uwagi na ich niezgodność z normami wyższego rzędu.

Nie wymaga szerszego uzasadnienia pogląd, iż każdorazowo, dochodząc do wątpliwości w zakresie zgodności z Konstytucją określonego przepisu, sąd orzekający powinien rozważyć skierowanie do Trybunału Konstytucyjnego pytania prawnego (art. 193 Konstytucji), albowiem obowiązywanie w systemie prawnym norm pustych (z uwagi na ich niekonstytucyjny charakter) nie jest pożądane i celowa jest ich formalna derogacja ${ }^{19}$.

\section{RAŻĄCA NIESPRAWIEDLIWOŚĆ ROZSTRZYGNIĘCIA WYNIKAJĄCA Z WYKŁADNI JĘZYKOWEJ}

Co do drugiego przypadku powołanego przez SN, to należy zauważyć, że pozostaje on w bezpośredniej bliskości z pierwszą sytuacją, albowiem ,sprzeczność z fundamentalnymi wartościami konstytucyjnymi” bardzo często jednocześnie oznacza, że doszło do wydania rozstrzygnięcia, które można określić jako „rażąco niesłuszne, niesprawiedliwe, nieracjonalne lub niweczące ratio legis interpretowanego przepisu".

O ile pierwszy wyjątek nawiązuje w większym stopniu do wykładni systemowej, to drugi wywodzi się z wykładni funkcjonalnej, ponieważ jedna z jej reguł stanowi, że: „Przy interpretacji przepisów prawnych należy brać pod uwagę powszechnie akceptowane normy moralne, zasady sprawiedliwości i słuszności”20.

Tu trzeba jednak podnieść, że odwoływanie się do tego kryterium powinno cechować się szczególną ostrożnością. W opinii publicznej kontrowersyjna jest bowiem kwestia penalizacji np. posiadania środków odurzających (art. 62 ust. 1 ustawy o przeciwdziałaniu narkomanii ${ }^{21}$ ), czy spożywania napojów alkoholowych „w miejscu publicznym” (art. $43^{1}$ ust. 1 ustawy o wychowaniu w trzeźwości i przeciwdziałaniu alkoholizmowi ${ }^{22}$ ). Zdaniem części społeczeństwa każdorazowe skazanie bądź ukaranie za te czyny zabronione może być „rażąco niesłuszne” lub „niesprawiedliwe”. Oparcie się na społecznym poczuciu sprawiedliwości nie jest jednak wystarczające do wykluczenia stosowania określonych regulacji, tym bardziej, gdy stwierdzono ich zgodność z Konstytucją ${ }^{23}$. Ponadto celem wprowa-

19 Wyrok TK z dnia 14 lipca 2010 r., OTK-A 2010, nr 6, poz. 59; wyrok TK z dnia 30 października 2006 r., OTK-A 2006, nr 9, poz. 128.

20 L. Morawski, Wstęp, s. 151.

21 Dz. U. 2018, poz. 1030, ze zm.

22 Dz. U. 2018, poz. 2137.

${ }_{23} \mathrm{Na}$ temat art. 62 ust. 1 u.p.n. wypowiedział się Trybunał Konstytucyjny w wyroku z dnia 4 listopada 2014 r., SK 55/13, OTK-A 2014, nr 10, poz. 111. 
dzenia tych regulacji jest ochrona określonych dóbr prawnych i wbrew wykładni funkcjonalnej byłoby odmówienie ich stosowania.

Wypada w tym miejscu jednak uczynić zastrzeżenie, że zawodne może okazać się rozszerzanie odpowiedzialności karnej z odwołaniem się do wyżej wskazanego celu jaką jest ochrona dóbr prawnych. Trzeba bowiem sobie zdawać sprawę z tego, że prawo karne jest instrumentem ultima ratio, wykorzystywanym do ochrony określonych wartości jedynie w ostateczności, gdy pozostałe środki są niewystarczające (art. 31 ust. 3 Konstytucji). W związku z tym przyjmuje się, że norma sankcjonowana (wprowadzająca zakaz lub nakaz określonego zachowania) generalnie ma swoje źródło w przepisach innych gałęzi prawa niż prawo karne; jedynie wyjątkowo prawo karne wprowadza własne normy sankcjonowane, dotyczące np. usiłowania zaatakowania dobra bądź zakazów obyczajowych (np. art. 201, 202 k.k.) ${ }^{24}$. Oznacza to, że prawo karne w pewien sposób „zabezpiecza” (pod groźbą kary) wykonanie określonych zakazów i nakazów.

Jest to szczególnie interesujące na gruncie sprawy rozstrzygniętej uchwałą SN, sygn. I KZP 35/08. Sąd Najwyższy, opierając się na językowym brzmieniu art. $265 \S 1$ k.k., dokonał rozszerzającej wykładni art. $265 \S 1$ k.k., przyjmując, iż skoro nie zawiera on jakiegokolwiek zawężenia w zakresie znamienia podmiotu przestępstwa, to trzeba przyjąć, że przestępstwo ujawnienia informacji ma charakter powszechny. Pomocniczym argumentem systemowym było odwołanie się do treści art. $265 \S 3$ k.k. (gdzie ustawodawca wprost zawarł ograniczenie podmiotowe). SN uznał również, że art. $265 \S 1$ k.k. formułuje odrębną normę sankcjonowaną, co znajduje dodatkowo oparcie w art. 82 Konstytucji określającym obowiązki obywatela Rzeczypospolitej Polskiej. Najwyższa instancja sądowa odwołała się również do wykładni funkcjonalnej, albowiem dobra chronione w art. $265 \S 1$ k.k. „to wartości, których zabezpieczenie warunkuje również bezpieczeństwo innych prawnie chronionych dóbr obywateli”, co „uzasadnia szeroki zakres penalizacji zachowań, które w nie godzą".

Pogląd przedstawiony przez SN stanowi ciekawy przykład nieskrępowanej niczym wykładni językowej, prowadzącej do naruszenia zasad prawa karnego, co w tym wypadku jest niezgodne przede wszystkim z wykładnią systemową. Trzeba bowiem mieć na uwadze, że względy systemowe zupełnie nie uzasadniają rozumowania SN (czynią to jedynie względy językowe), natomiast odwołanie się do wykładni funkcjonalnej jest na tyle ogólne, że może zostać użyte w dowolnej sprawie dotyczącej określenia zakresu penalizacji zachowań społecznie niepożądanych ${ }^{25}$.

Podobnie jest zresztą z zastosowaniem w tej sprawie art. 82 Konstytucji; jest to o tyle niezrozumiałe, że sprawa rozpatrywana przez SN dotyczyła dziennikarzy,

${ }^{24}$ W. Wróbel, A. Zoll, Polskie prawo karne, Kraków 2013, s. 110.

25 Zob. też M. Leciak, Glosa do uchwały Sądu Najwyższego z dnia 26 marca 2009 r., sygn. I KZP 35/08, „Prokuratura i Prawo” 2009, nr 9, s. 167. 
którzy informowali o działalności szpiegowskiej w strukturach państwowych, a zatem umożliwiali innym podmiotom korzystanie z prawa do informacji, a przy tym sami korzystali z prawa do rozpowszechniania informacji. Na tej tylko podstawie nie można przecież powiedzieć, że w ten sposób nie dochowują wierności państwu lub nie działają w trosce o dobro wspólne. W dodatku jest to interpretacja rozszerzająca obowiązki obywatela ${ }^{26}$.

Przepis art. $265 \S 1$ k.k. wyraźnie wskazuje (i wskazywał także wtedy, gdy dotyczył ujawnienia ,informacji stanowiących tajemnicę państwową"), iż ujawnienie lub wykorzystanie informacji ma nastąpić „wbrew przepisom ustawy”, co interpretatorowi daje wyraźny sygnał, iż źródłem normy sankcjonowanej są inne przepisy niż prawnokarne przepisy dotyczące ochrony informacji ${ }^{27}$. Tym samym wykluczone jest interpretowanie tej normy wyłącznie z art. $265 \S 1$ k.k., tym bardziej, że prowadzi to do bardzo szerokiego pola penalizacji. Skoro doszukiwanie się normy sankcjonowanej wyłącznie w przepisach prawa karnego jest wyjątkiem, to praktyka zaakceptowana przez SN niewątpliwie jest sprzeczną z zakazem wykładni rozszerzającej wyjątków i choćby na tej podstawie powinna być odrzucona ${ }^{28}$.

Niczego w tej materii nie zmienia odwołanie się do art. $265 \S 3$ k.k., gdzie znamię indywidualizujące zostało określone wprost. Indywidualny charakter tego przestępstwa wynika bowiem $\mathrm{z}$ art. 1 ust. 2 ustawy o ochronie informacji niejawnych ${ }^{29}$, który wyraźnie określił podmioty, do których skierowane są zakazy i nakazy dotyczące postępowania z informacjami niejawnymi. Na tle powyższej ustawy można wysunąć całkiem prawdopodobne przypuszczenie, iż celem art. 265 $\S 1$ k.k. odczytywanego w kontekście art. 1 ust. 2 u.o.i.n. jest właśnie zawężenie penalizacji, a nie jej rozszerzenie. Wszak art. 5 ust. 1 ustawy z 1982 r. o ochronie tajemnicy państwowej i służbowej ${ }^{30}$ stanowił: „Zachowanie tajemnicy państwowej jest obowiązkiem każdego, do czyjej wiadomości dotarła". Podobnego przepisu brakuje w nowej ustawie, co oznacza, że, gdyby intencją ustawodawcy było utrzymanie powszechnego obowiązku ochrony tajemnicy państwowej, to art. 5 ust. 1 zostałby utrzymany także w obecnym stanie prawnym ${ }^{31}$.

26 Przy tym budzi wątpliwości w kontekście art. 31 ust. 3 Konstytucji (J. Skrzydło, Glosa do uchwały z 26 III 2009, I KZP 35/08, „Państwo i Prawo” 2010, nr 6, s. 132-133; M. Leciak, Glosa, s. 166).

27 J. Raglewski, Glosa do uchwały SN z dnia 26 marca 2009 r., I KZP 35/08, LEX/el. 2009; M. Leciak, Glosa, s. 160-165; W. Wróbel [w:] Kodeks karny. Część szczególna, t. 2, cz. 2: Komentarz do art. art. 212-277d, red. W. Wróbel, A. Zoll, Warszawa 2017, komentarz do art. 265, teza 12; W. Zontek, Sposoby wyznaczania zakresu treści normy sankcjonowanej. Uwagi na marginesie uchwały SN z 26 marca 2009 r., sygn. akt I KZP 35/08 (cz. 1), „Palestra” 2009, nr 11-12, s. 38.

28 Zob. również tenże, Sposoby wyznaczania zakresu treści normy sankcjonowanej. Uwagi na marginesie uchwały SN z 26 marca 2009 r., sygn. akt I KZP 35/08 (cz. 2), „Palestra” 2010, nr 1-2, s. 56.

29 Dz. U. 2018, poz. 412, ze zm.

30 Dz. U. 1982, nr 40, poz. 271, ze zm.

31 J. Raglewski, Glosa; M. Leciak, Glosa, s. 166; J. Skrzydło, Glosa, s. 130; W. Zontek, Sposoby (cz. 2), s. 50-52. 
Przedstawiony sposób argumentacji, mający licznych zwolenników w doktrynie prawa karnego, prowadzi do znacznego zawężenia zastosowania przepisu wprowadzającego odpowiedzialność karną za czyn polegający na ujawnieniu lub wykorzystaniu informacji o klauzule „tajne” lub ,ściśle tajne”, pomimo jego prima facie bezdyskusyjnego językowego brzmienia. $Z$ pewnością nie można postawić mu zarzutu, że prowadzi do przypisania sądowi prawotwórczej roli, jeżeli uwzględni się systemowy kontekst w jakim art. $265 \S 1$ k.k. występuje.

Trzeba mieć przy tym na uwadze, że przepisy prawne charakteryzują się otwartą tekstowością. Zmieniająca się rzeczywistość wymusza nadawanie danym pojęciom prawnym różne znaczenie w zależności od zmieniających się warunków społecznogospodarczych i rozwoju technologicznego. Przykładem tego typu jest wykładnia znamienia „włamanie” w kontekście art. 279 § 1 k.k. i zaborów mienia dokonywanych po przełamaniu elektronicznych zabezpieczeń kart płatniczych po uprzednim wpisaniu kodu PIN. Choć wydaje się to nie mieścić w językowym znaczeniu pojęcia „włamanie” (szczególnie uwzględniając jedynie definicje słownikowe), tak rażąco niesłuszne i nieprzystające do obecnych realiów, byłoby nietraktowanie tego jako włamania, skoro sprawca wpisując kod przełamuje przeszkodę chroniącą dostęp do pieniądza w postaci elektronicznej ${ }^{32}$.

\section{BŁĄD LEGISLACYJNY I ABSURDALNY WYNIK WYKŁADNI JĘZYKOWEJ}

Odnosząc się do dwu pozostałych przypadków wymienionych przez Sąd Najwyższy, należy zauważyć, że również i one są do siebie podobne. Często jest tak, że błąd legislacyjny prowadzi do absurdu w sferze stosowania prawa.

$\mathrm{Z}$ niewątpliwym absurdem mamy do czynienia na gruncie art. $64 \S 3$ k.k., który zakazuje wymierzenia sprawcy zbrodni kary przekraczającej górną granicą ustawowego zagrożenia w przypadku, gdy spełnione są w jego przypadku przesłanki recydywy specjalnej (art. 64 § 1 i 2 k.k.). Prowadzi to do sytuacji, w której sprawcy przestępstwa $\mathrm{z}$ art. $280 \S 2 \mathrm{k}$.k. grozi kara maksymalnie 15 lat pozbawienia wolności, natomiast skazanemu za występek z art. $280 \S 1$ k.k. można wymierzyć maksymalnie 18 lat pozbawienia wolności (art. 38 § 2 k.k. pozwala bowiem, w razie nadzwyczajnego obostrzenia kary, wymierzyć maksymalnie 20 lat pozbawienia wolności, co stanowi odstępstwo od, wyrażonej w art. 37 k.k., zasady, iż kara pozbawienia wolności może wynosić maksymalnie 15 lat pozbawienia wolności). W doktrynie jako oczywiste traktuje się wady ww. regulacji, jednocześnie akcentu-

32 Wyrok SA w Gdańsku z dnia 10 maja 2018 r., II AKa 97/18, LEX nr 2607665; wyrok SN z dnia 22 marca 2017 r., III KK 349/16, OSNKW 2017, nr 9, poz. 50. 
jąc, że w warstwie językowej art. $64 \S 3$ k.k. jest zupełnie jasny ${ }^{33}$. Co ciekawe, pomimo świadomości absurdalnych konsekwencji takiej wykładni, nikt nie postuluje, aby interpretować art. $64 \S 3$ k.k. wbrew jego językowemu brzmieniu, a w zgodzie $\mathrm{z}$ racjami systemowymi (albowiem w obecnej wersji art. $64 \S 3$ k.k. nie przystaje do pozostałych przepisów regulujących recydywę specjalną) bądź funkcjonalnymi (ponieważ art. $64 \S 3$ k.k. nie prowadzi do zaostrzenia odpowiedzialności karnej powrotnych sprawców zbrodni, wbrew zakładanym celom instytucji recydywy). Wręcz przeciwnie, J. Majewski argumentuje, że odmienne rozumowanie byłoby sprzeczne z zakazem wykładni per non est i prowadziłoby do niedopuszczalnej wykładni rozszerzającej na niekorzyść sprawcy ${ }^{34}$. Zakaz wykładni per non est wywodzi się z postulatu racjonalnego ustawodawcy i zakazuje interpretować przepisy prawne w sposób prowadzący do uznania, że jego fragmenty są zbędne ${ }^{35}$. Tym bardziej niedopuszczalna jest wykładnia prowadząca do wyłączenia mocy obowiązującej całego przepisu (oczywiście wtedy, gdy nie ma to oparcia np. w wykładni prokonstytucyjnej).

Nie da się ukryć, że przyznanie pierwszeństwa metodzie systemowej i funkcjonalnej, w całkowitej sprzeczności z językową, prowadziłoby do traktowania art. $64 \S 3$ k.k. jako nieistniejący i stanowiłoby ewidentny przykład wykładni prawotwórczej, zakładającej ustawodawcze uprawnienia sądu. De lege lata art. $64 \S 3$ k.k. należy traktować jako błąd legislacyjny, który może poprawić jedynie ustawodawca.

Podobne problemy występowały na gruncie art. $4 \S 2$ k.k. w brzmieniu obowiązującym do 30 czerwca 2015 r. Przepis ten wówczas stanowił: „Jeżeli według nowej ustawy za czyn objęty wyrokiem nie można orzec kary w wysokości kary orzeczonej, wymierzoną karę obniża się do wysokości najsurowszej kary możliwej do orzeczenia na podstawie nowej ustawy” (obecnie: „Jeżeli według nowej ustawy za czyn objęty wyrokiem nie można orzec kary w wysokości kary orzeczonej, wymierzoną karę obniża się do wysokości najsurowszej kary możliwej do orzeczenia na podstawie nowej ustawy"). Wadliwość tej regulacji objawiała się w przypadku obniżenia kary wymierzonej wobec recydywisty w wysokości przekraczającej górną granicę ustawowego zagrożenia. Przykładowo, karę 13 lat pozbawienia wolności za rozbój należało obniżyć do 12 lat. Nie uwzględniało to faktu, iż sprawca podlegał zaostrzonej odpowiedzialności na mocy uprzedniej karalności.

Sądy, pomimo względów funkcjonalnych, interpretowały ten przepis ściśle językowo. Uznawały mianowicie, że w tym przepisie chodzi o górną granicę usta-

33 J. Majewski [w:] Kodeks karny. Część ogólna, t. 1, cz. 2: Komentarz do art. 53-116, red. W. Wróbel, A. Zoll, Warszawa 2016, komentarz do art. 64, teza 8; P. Czarnecki, P. Hofmański, L. K. Paprzycki [w:] Kodeks karny. Komentarz, red. M. Filar, Warszawa 2016, komentarz do art. 64, teza 19.

34 J. Majewski [w:] Kodeks..., komentarz do art. 64, teza 8.

35 L. Morawski, Wstęp, s. 148. 
wowego zagrożenia, a nie „maksymalną karę jaką można wymierzyć za dane przestępstwo" 36 .

Niemożliwym jest oczywiście zbadanie wszystkich przypadków budzących wątpliwości, jeżeli chodzi o racjonalność ścisłego trzymania się wykładni językowej. W ww. obu przypadkach przyjmowano wszak, że wadliwe sformułowanie przepisu nie może być interpretowane w sposób nieliczący się z jego językowym brzmieniem, szczególnie, gdy ma to nastąpić na niekorzyść sprawcy.

Zdarzają się jednak przypadki, gdy wykładnia systemowa i funkcjonalna pozwala uzyskać prawidłowy rezultat niejednoznacznej wykładni językowej. Tak jest w przypadku art. $60 \S 7$ k.k., który stanowi: „Jeżeli czyn zagrożony jest więcej niż jedną z kar wymienionych w art. 32 pkt 1-3, nadzwyczajne złagodzenie kary polega na odstąpieniu od wymierzenia kary i orzeczeniu środka karnego wymienionego w art. 39 pkt 2-3, 7 i 8, środka kompensacyjnego lub przepadku". Pozostawanie jedynie przy wykładni językowej mogłoby skłaniać do wniosku, że w przypadku przestępstwa $z$ art. 53 ust. 2 u.p.n. (zagrożonego grzywną i pozbawieniem wolności) nadzwyczajne złagodzenie polega na odstąpieniu od wymierzenia kary. Tymczasem, po pierwsze należy wziąć pod uwagę względy systemowe, w szczególności art. 60 $\S 6$ pkt 2 k.k., którego językowe brzmienie jest jasne i który nakazuje, w przypadku nadzwyczajnego złagodzenia kary za zbrodnie, wymierzyć karę pozbawienia wolności w wysokości przynajmniej 1/3 dolnej granicy ustawowego zagrożenia. Po drugie, wykładnia funkcjonalna nakazuje uwzględniać, że nadzwyczajny wymiar kary za zbrodnie nie może prowadzić do łagodniejszych konsekwencji niż nadzwyczajne złagodzenie kary w przypadku cięższych występków (art. $60 \S 6$ pkt 3 k.k.), gdzie dojdzie choćby do wymierzenia grzywny ${ }^{37}$.

Niekiedy judykatura próbuje w sposób nieuprawniony zastępować władzę ustawodawczą, próbując przełamać jednoznaczne rezultaty wykładni językowej, przy czym zbieżne z tym są wnioski wynikające z pozostałych metod wykładni. Jest oczywiste, że tego typu praktyka jest zakazana, gdy prowadzi to do poszerzenia zakresu odpowiedzialności karnej. Trudno się z tym zgodzić także wtedy, gdy następuje to na korzyść sprawcy, a nie uzasadniają tego względy pozajęzykowe

36 Postanowienie SN z dnia 20 października 1999 r., II KKN 199/99; Prokuratura i Prawo-wkł. 2000, nr 6, poz. 1; postanowienie SN z dnia 6 września 2000 r., III KKN 337/00, OSNKW 2000, nr 9-10, poz. 81.

37 Zob. też K. Kmąk, Sankcje kumulatywne od 1 lipca 2015 r. - rozważania na tle ustawy o przeciwdziałaniu narkomanii, „Prokuratura i Prawo” 2018, nr 10, s. 118; J. Majewski [w:] Kodeks karny. Komentarz do zmian 2015, Warszawa 2015, komentarz do art. 60, teza 8; wyrok SA w Lublinie z dnia 25 stycznia 2018 r., II AKa 251/17, LEX nr 2453731; wyrok SA w Katowicach z dnia 4 kwietnia 2018 r., II AKa 97/18, LEX nr 2490247; por. K. Janczukowicz, Nadzwyczajne złagodzenie kary za przestępstwa o zagrożeniu wielorodzajowym [w:] Kodeks karny. Omówienie zmian wprowadzonych ustawą z dnia 20 lutego 2015 r. o zmianie ustawy - Kodeks karny oraz niektórych innych ustaw (Dz. U. z 2015 r., poz. 396), LEX/el. 2015. 
(odmiennie niż w sprawie I KZP 35/08). Przykładem tego jest linia orzecznicza, która wykształciła się na gruncie art. 62 ust. 1 ustawy o przeciwdziałaniu narkomanii, który penalizuje posiadanie, wbrew przepisom ustawy, środków odurzających lub substancji psychotropowych. Stosując wszystkie metody wykładni, należy dojść do wniosku, że norma sankcjonowana w tym wypadku zakazuje posiadania jakiejkolwiek ilości wskazanych środków lub substancji. Odrębną kwestią jest karygodność przypadków, gdy sprawca posiada te środki w znikomej ilości, a także trudności dowodowe przejawiające się w konieczności wykazania, że konkretny sprawca posiadał substancje niedozwolone w takiej ilości, którą trudno zmierzyćc ${ }^{38}$. Tymczasem orzecznictwo jednomyślnie dopatruje się w tym wypadku luki prawnej, ponieważ „W wymienionym przepisie nie określono (...) minimalnej dawki środka odurzającego lub substancji psychotropowej, których posiadanie rodzi odpowiedzialność karną, ${ }^{39}$, a zatem „Na podstawie art. 62 ustawy z dnia 29 lipca 2005 r. o przeciwdziałaniu narkomanii (...) karalny jest każdy wypadek posiadania środka odurzającego lub substancji psychotropowej "wbrew przepisom ustawy", (...) jeżeli sprawca posiada środek odurzający lub substancję psychotropową w ilości pozwalającej na co najmniej jednorazowe użycie, w dawce dla nich charakterystycznej, zdolnej wywołać u człowieka inny niż medyczny skutek" ${ }^{\prime 40}$.

\section{PODSUMOWANIE}

Powyższe rozważania świadczą o tym, że do wypadków, określonych przez Sąd Najwyższy i L. Morawskiego jako pozwalające na odstąpienie od rezultatów wykładni językowej, należy w prawie karnym podchodzić z dużą ostrożnością. Przede wszystkim, nigdy nie może to prowadzić do pogorszenia sytuacji sprawcy, nawet jeżeli przemawiają za tym względy systemowe i funkcjonalne, a to ze względu np. na zakaz wykładni rozszerzającej i zakaz analogii na niekorzyść sprawcy. Te ostatnie racje mogą przesądzić o przyjętym kierunku wykładni tylko wtedy, gdy językowa interpretacja daje niejednoznaczne wyniki. Najdalej idące (i kon-

${ }_{38}$ Podobnie M. Kulik, Komentarz do niektórych przepisów ustawy o przeciwdziałaniu narkomanii [w:] Pozakodeksowe przestępstwa przeciwko zdrowiu. Komentarz, red. M. Mozgawa, Warszawa 2017, teza 9.

39 Postanowienie SN z dnia 28 października 2009 r., I KZP 22/09, OSNKW 2009, nr 12, poz. 103.

40 Tamże; podobnie wyrok SN z dnia 20 kwietnia 2011 r., IV KK 26/11, LEX nr 794512; wyrok SN z dnia 11 marca 2010 r., IV KK 432/09, LEX nr 583908; wyrok SN z dnia 20 stycznia 2010 r., II KK 289/08, LEX nr 570140; wyrok SN z dnia 16 kwietnia 2009 r., IV KK 418/08, OSNKW 2009, nr 7, poz. 53; wyrok SA w Białymstoku z dnia 7 grudnia 2006 r., II AKa 249/06, OSAB 2006, nr 4, poz. 38; wyrok SN z dnia 18 maja 2017 r., IV KK 444/16, LEX nr 2306381; wyrok SA w Warszawie z dnia 23 grudnia 2013 r., II AKa 422/13, LEX nr 1416397. 
trowersyjne) jest wykluczenie stosowania określonego przepisu na podstawie jego niezgodności z normami wyższego rzędu (zwłaszcza konstytucyjnymi), co jednak powinno każdorazowo kończyć się stwierdzeniem jego niekonstytucyjności przez Trybunał Konstytucyjny.

W takim rozumieniu opisane powyżej wyjątki nie stanowią wykładni prawotwórczej, więc należy je uznać za generalnie dopuszczalne na gruncie prawa karnego. Tytułowe orzeczenie, wskazujące ogólnie sytuacje pozwalające na odstąpienie od rezultatów wykładni językowej, zasługuje na aprobatę w tym zakresie, aczkolwiek jednocześnie pokazuje do czego może prowadzić bezkrytyczne podążanie za prymatem wykładni językowej w tak wrażliwej dziedzinie jak prawo karne. Sąd Najwyższy przyjął bowiem za właściwą interpretację art. $265 \S 1$ k.k. w sposób najbardziej zgodny z jego językowym brzmieniem, nie dostrzegając, że wykładnia systemowa i funkcjonalna pełni w tym przypadku rolę korygującą i doprecyzowującą treść znamion czynu zabronionego ${ }^{41}$, a jednocześnie wyniki uzyskane za pomocą tych metod wykładni mieszczą się również w zakresie wykładni językowej.

\section{BIBLIOGRAFIA}

Hofmański P., Zabłocki S., Elementy metodyki pracy sędziego w sprawach karnych, Warszawa 2011. Janczukowicz K., Nadzwyczajne złagodzenie kary za przestępstwa o zagrożeniu wielorodzajowym, [w:] Kodeks karny. Omówienie zmian wprowadzonych ustawą z dnia 20 lutego 2015 r. o zmianie ustawy - Kodeks karny oraz niektórych innych ustaw (Dz. U. z 2015 r., poz. 396), LEX/el. 2015.

Kardas P., Problem reakcji na tzw. czyny przepołowione w świetle ciągłości popełnienia przestępstwa, konstrukcji idealnego zbiegu czynów karalnych oraz zasady ne bis in idem, „Prokuratura i Prawo" 2018, nr 3.

Kmąk K., Sankcje kumulatywne od 1 lipca 2015 r. - rozważania na tle ustawy o przeciwdziałaniu narkomanii, „Prokuratura i Prawo” 2018, nr 10.

Kodeks karny. Część ogólna, t. 1, cz. 1: Komentarz do art. 1-52, red. W. Wróbel, A. Zoll, Warszawa 2016.

Kodeks karny. Część ogólna, t. 1, cz. 2: Komentarz do art. 53-116, red. W. Wróbel, A. Zoll, Warszawa 2016.

Kodeks karny. Część szczególna, t. 2, cz. 2: Komentarz do art. art. 212-277d, red. W. Wróbel, A. Zoll, Warszawa 2017

Kodeks karny. Komentarz, red. M. Filar, Warszawa 2016.

Leciak M., Glosa do uchwały Sądu Najwyższego z dnia 26 marca 2009 r., sygn. I KZP 35/08, „Prokuratura i Prawo" 2009, nr 9.

Majewski J., Kodeks karny. Komentarz do zmian 2015, Warszawa 2015.

${ }^{41} \mathrm{Z}$ tego punktu widzenia nie można uznać za teoretycznie poprawne zdanie SN wyrażone w postanowieniu z dnia 21 listopada 2001 r., I KZP 27/01, LEX nr 49714, iż ,jednoznaczne sformułowanie (...) przepisów wyklucza korygowanie ich treści za pomocą innych metod wykładni, w tym celowościowej czy systemowej. Taki zabieg w istocie prowadziłby do uchylania w drodze interpretacji mocy obowiązującej prawa stanowionego". 
Morawski L., Wstęp do prawoznawstwa, Toruń 2014.

Postanowienie SN z dnia 20 października 1999 r., II KKN 199/99; Prokuratura i Prawo-wkł. 2000, nr 6, poz. 1 .

Postanowienie SN z dnia 6 września 2000 r., III KKN 337/00, OSNKW 2000, nr 9-10, poz. 81.

Raglewski J., Glosa do uchwały SN z dnia 26 marca 2009 r., I KZP 35/08, LEX/el. 2009.

Rychlewska A., O gwarancyjnym modelu wykładni prokonstytucyjnej przepisów typizujących czyny zabronione pod groźbą kary, „Czasopismo Prawa Karnego i Nauk Penalnych” 2016, z. 3.

Skrzydło J., Glosa do uchwały z 26 III 2009, I KZP 35/08, „Państwo i Prawo” 2010, nr 6.

Uchwała SN z dnia 26 marca 2009 r., I KZP 35/08, OSNKW 2009, nr 5, poz. 33.

Wróbel W., Zoll A., Polskie prawo karne, Kraków 2013.

Wyrembak J., Zasadnicza wykładnia znamion przestępstw. Pozycja metody językowej oraz rezultatów jej użycia, Warszawa 2009.

Wyrok SA w Katowicach z dnia 4 kwietnia 2018 r., II AKa 97/18, LEX nr 2490247.

Wyrok SA w Lublinie z dnia 25 stycznia 2018 r., II AKa 251/17, LEX nr 2453731.

Wyrok TK z dnia 14 lipca 2010 r., OTK-A 2010, nr 6, poz. 59.

Wyrok TK z dnia 30 października 2006 r., OTK-A 2006, nr 9, poz. 128.

Wyrok TK z dnia 4 listopada 2014 r., SK 55/13, OTK-A 2014, nr 10, poz. 111.

Zieliński M., Osiemnaście mitów w myśleniu o wykładni prawa.

Zieliński M., Wykładnia prawa. Zasady, reguły, wskazówki, Warszawa 2012.

Zontek W., Sposoby wyznaczania zakresu treści normy sankcjonowanej. Uwagi na marginesie uchwały SN z 26 marca 2009 r., sygn. akt I KZP 35/08 (cz. 1), „Palestra” 2009, nr 11-12.

Zontek W., Sposoby wyznaczania zakresu treści normy sankcjonowanej. Uwagi na marginesie uchwały SN z 26 marca 2009 r., sygn. akt I KZP 35/08 (cz. 2), „Palestra” 2010, nr 1-2.

\section{SUMMARY}

The article describes situations in which it is permissible to depart from the results of a linguistic interpretation. L. Morawski enumerated these situations. Then Supreme Court adapted it in penal law. However, it has been accused that acceptance of such proceedings leads to acceptance of the law-making interpretation. The analysis of the these cases leads to the conclusion that departure from the results of the linguistic interpretation in criminal law is generally acceptable, as long as it does not constitute an interpretation that is not favorable for the perpetrator and is based on system and functional interpretation.

Keywords: penal law; interpretation, Supreme Court. 